\title{
LUA DE FEL: DA PAIXÃO À REPULSA; DAS TENTAÇÕES ÀS EVIDÊNCIAS DO DESEJO
}

\section{Bene Martins Marco Antônio Moreira Carvalho UFPA}

\section{Resumo}

O filme Lua de Fel (Bitter Moon) (1992) apresenta as ligações obscuras entre os casais. A trama perpassa a linha do subjetivo, num jogo perverso entre o aspecto estético e o ético. Neste texto, traçaremos considerações acerca do filme, cuja trama expõe relações erótico-amorosas em suas complexidades. Dois casais, em um luxuoso cruzeiro. Um, britânico, em segunda Lua de Mel, numa tentativa de aquecer o casamento de sete anos que apresenta sinais de cansaço e desânimo; outro, americano, em uma espécie de relacionamento doentio e sádico, divertese a provocar o casal modelo que, à primeira vista, parece ser conservador. Nossa análise focará primeiro, a paixão arrebatadora, a delicadeza do envolvimento; em seguida, o desgaste, a perda do desejo, o sadismo, a fragilidade das relações encobertas e rejeitadas para uns, escancaradas para outros. Segundo, enfocaremos planos adequados que deram ênfase e veracidade aos conflitos e jogos de sedução. Estudos sobre erotismo, paixão, amor, nos guiaram para uma das tantas leituras instigadoras que a película incita.

\section{Palavras-chave:}

Cinema; Erotismo; Paixão; Desejo.

Efetivamente, a transgressão que ainda não fora cometida tinha um valor que a repetição não tem. Efetivamente, o que me interessa é a entrada, não a permanência no mundo interdito, o que me apraz é quebrar minhas correntes; não fico olhando para as correntes quebradas. (Georges Bataille).

\section{INTRODUÇÃO}

Este filme de Roman Polanski ${ }^{1}$, roteirizado a partir do romance, Lunes de FieP, 1981, de Pascal Bruckner, mantém ponto caro ao autor, a relação erótico-amorosa, sadomasoquista de

\section{Abstract}

The film Lua de Fel (Bitter Moon) (1992) presents the obscure links between couples. The plot crosses the line of the subjective, in a perverse game between the aesthetic and the ethical aspect. In this text, we will draw considerations on the film, celebrate plot exposes erotic-loving relationships in their complexities. Two couples on a luxury cruise. A British, second honeymoon, in an attempt to warm up at the seven-year marriage that shows signs of weariness and discouragement; Another, American, in a kind of sick and sadistic relationship, amuses himself to provoke the couple model, at first glance, it seems to be conservative. Our analysis will focus first, a rapturous passion, a delicacy of involvement; instead, weariness, loss of desire, sadism, fragility of relationships concealed and rejected for some, wide open to others. Second, we will focus on adequate plans that have emphasized and verified conflict and seduction games. Studies on eroticism, passion, love, have guided us to one of the many instigating readings that the film incites.

Keywords:

Cinema; Eroticism; Passion; Desire.

Oscar e Mimi. Ele, paraplégico, ela, belíssima, sensual, misteriosa. A epígrafe de Geoges Bataille enuncia o que virá, a inevitável transgressão. Não há porque protelar, quem assistiu ao filme, percebe, desde o início que o casal, em lua de mel, entrará no espaço do interdito e do proibido. Este mote é um dos pontos altos do romancefilme que, desde logo, aponta indícios de que amarras serão rompidas, nessa viagem por espaços geográficos-subjetivos-libidinosostransgressores. Num jogo de sedução irresistível, o sádico Oscar (Peter Coyote) e a bela Mimi (Emmanuelle Seigner) cercam Nigel (Hugh Grant) e sua esposa Fiona (Kristin Scott 


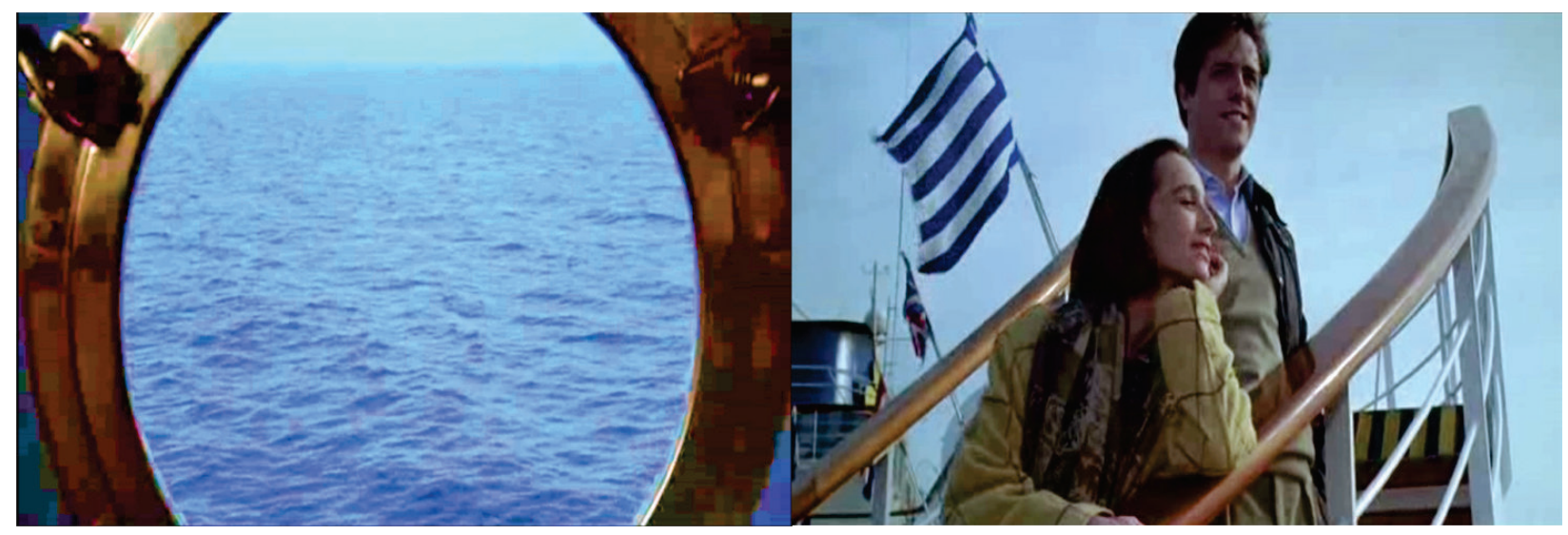

Figura 1 - Cena de abertura do filme mostra o mar calmo. Os personagens Nigel e Fiona, alegres, comemoram a viagem para a Índia. Fonte: frames extraídos do filme Lua de Fel(1992) pelos autores.

Thomas). A partir daqui, os diálogos ferinos demonstram as reações dos indivíduos frente ao inesperado e inevitável desencadear de desejos camuflados e reprimidos de maneira consciente ou inconsciente.

Um dos casais invade a privacidade do outro, provoca e convence o outro a sair da zona de conforto matrimonial, experimentar outras sensações até então negadas. Sem julgamento, entendemos que o importante é despertar outro olhar para os vulneráveis encontros e relações entre pessoas tão diferentes e tão próximas, no que se refere a fantasias sexuais e a comportamentos inusitados, latentes e à espera de motivos e situações (in)adequadas para surgirem fortes e incontroláveis. Pessoas que, caem na armadilha de jogadas para entrarem em outras cenas, mesmo que por breve tempo.

Conforme o roteiro, não por acaso, o casal escolhe como destino da viagem, a Índia, país considerado exótico em si, muito diferente de tudo já vivenciado por eles, na Inglaterra. Esta opção de lugar talvez assinale o desejo de chegar ao desconhecido, o que estaria implícito ou recalcado na relação duradoura do casal. A necessidade de explorar outras nuances e sutilezas de prazer, embora, não falassem sobre.

$\mathrm{Na}$ abertura do filme, Polanski apresenta diferenças e indícios entre suas personagens. Esta é uma das características da obra do diretor, induzir as primeiras impressões dos protagonistas que, posteriormente, surpreendem ao se revelarem distintas do que o público inicialmente percebeu, pela aparência e comportamento ou pela escolha de atores com fisionomias que indicam/sugerem suas personalidades ${ }^{3}$. O casal britânico, no navio, embalados por águas calmas, contempla a paisagem, tranquilos. 0 que seria uma segunda lua de mel tornar-se-ia, no entanto, uma aventura chocante, a qual desestabilizaria as certezas quanto a valores, emoções, fantasias, relacionamento seguro.

Outras personagens importantes, o indiano e sua filha pequena. Ele pergunta ao casal, o porquê de escolherem a Índia, como destino. Nigel responde sob o lugar-comum, ir atrás de serenidade interior. Ao que o indiano ironiza: "a síndrome do carma-nirvana! Mas a Índia é lugar barulhento e, para quem tem uma bela esposa, não precisa de terapia marital" (LUA, 1992). Situação meio constrangedora instala-se entre eles, mas, desconversam e fica aquele clima de sondagem, por parte do indiano, sobre o casal que, aparentemente, expressa união inabalável.

Na primeira noite da viagem, Fiona se recolhe. Nigel vai ao bar tomar um drinque, lá vê a bela Mimi - que já encontrara antes, quando sua mulher a ajuda no banheiro feminino, numa situação de fragilidade e angústia, Mimi passara mal e vomitava, fora amparada por Fiona - a cantar, dançar no palco e olhando para Nigel, de maneira sensual. Em seguida, vem ao balcão, Nigel fala com ela. Ela o ironiza, o acha sem senso de humor, sai provocadoramente. Ele fica 


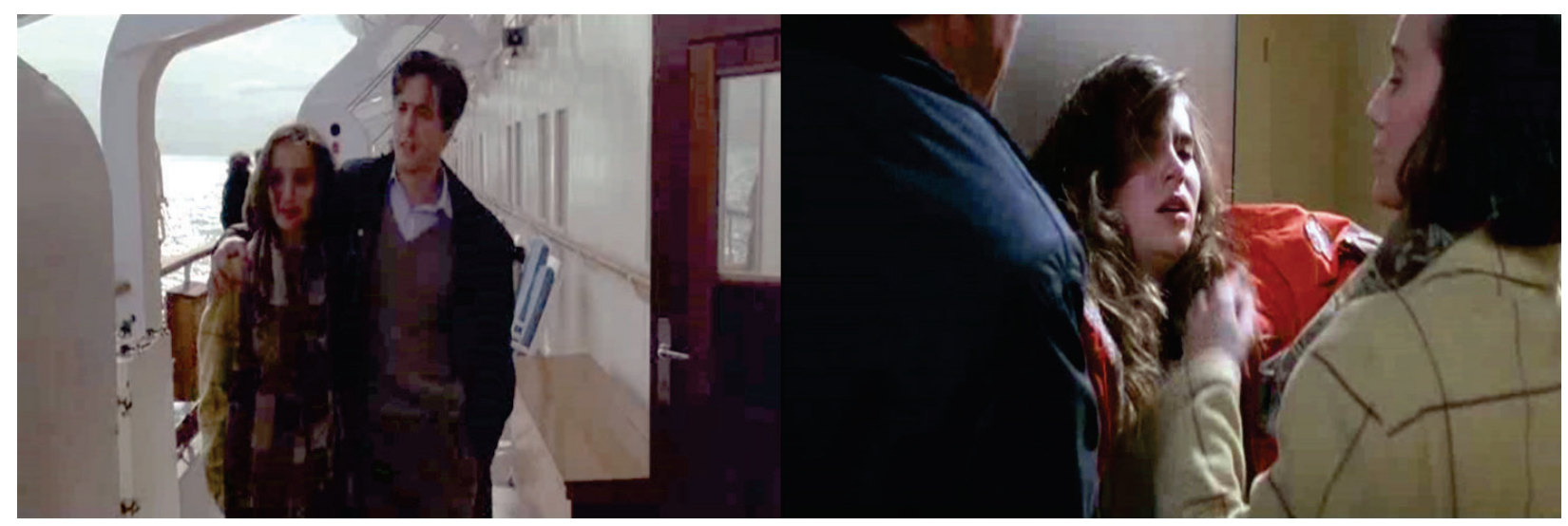

Figura 2 - Nigel e Fiona no navio e o primeiro encontro com Mimi. Fonte: frames extraídos do filme Lua de Fel (1992) pelos autores.

perturbado pela beleza e ousadia da mulher. Sai do bar e Oscar, de surpresa, o interpela, já perguntando se ele a desejava. Em seguida, o adverte: ela é armadilha para os homens, não é mulher para você. Apresenta-se como marido de Mimi e diz que ela é a responsável por ele estar aleijado, preso em cadeira de rodas e sob os cuidados da esposa. Insinua tantos suspenses e consegue a presa que queria para divertir-se durante a viagem.

Nigel nega o interessa pela bela Mimi e, daí em diante, o jogo de recusar-ceder terá várias partidas e fins. Em todas, Nigel perde, perdese, rende-se ao contador de detalhes sórdidos, os quais fascinam o homem bem casado, até então. Oscar afirma, Mimi é maravilhosamente bela, sedutora, perigosa e que ambos continuam juntos, numa espécie de dependência mórbida. Poder-se-ia afirmar, aqui, que Nigel, à semelhança de menino mimado, ao ser advertido da impossibilidade, tornar-se-ia mais interessado em obter aquela conquista, aquele objeto-erótico inalcançável por ele, criatura, cuja imaginação erótica encontravase enrustida.

Vários encontros inevitáveis os colocam em situações delicadas. Oscar percebe o disfarçado clima meio frio e distante do casal em busca de novos ares, elogia os encantos sutis de Fiona. Sem escrúpulo algum, invade a intimidade do casal, afirmando que ambos precisariam aquecer a relação. Insinua que a bela esposa de Nigel tem aquele ar de quem tem muito a ser explorado. Ante o espanto do britânico, ainda com sinais conservadores sobre esta experiência, o americano o desafia em seu modo de falar direto, sem filtro, sem limites, não mede palavras, vai direto aos pontos sensíveis de Nigel. Além de manter uma espécie de discurso apelativo, quando elabora frases em tom chantagista, faz-se de vítima, porque percebe a perturbação do ouvinte sentindo-se estranho com sensações outras.

Quando Nigel demonstra querer desistir de ouvir toda a história, Oscar, com cara de homem desamparado, apela, mais ou menos, nestes termos, "deixa pra lá, quem vai se interessar por um pobre aleijado (...). Mas você é o ouvinte que eu procurava. E eu, o interlocutor de desejos que você precisava" (LUA, 1992). Nigel, refinado demais para ser grosseiro, fica porque quer saber mais sobre a relação do casal. A cada encontro, mais escandalizado aparenta estar, mas continua a escutar os detalhes escabrosos; tenta fugir, não consegue, está inteiramente enredado na cilada armada pelo casal sadomasoquista.

Oscar conta que no início, viveram um belo romance, mas, transformado, aos poucos, numa relação de dependência mútua, na qual ambos alimentam-se de sentimentos confusos, de vingança, de maldade ora velada, ora explícita, de sexo, de um tipo de amor sofrido demais. Oscar insiste, "ela está Ihe dando tesão, não?" (LUA, 1992). Ante o desconforto do ouvinte, Oscar, ironiza: "ora Nigel, não seja tão britânico, 


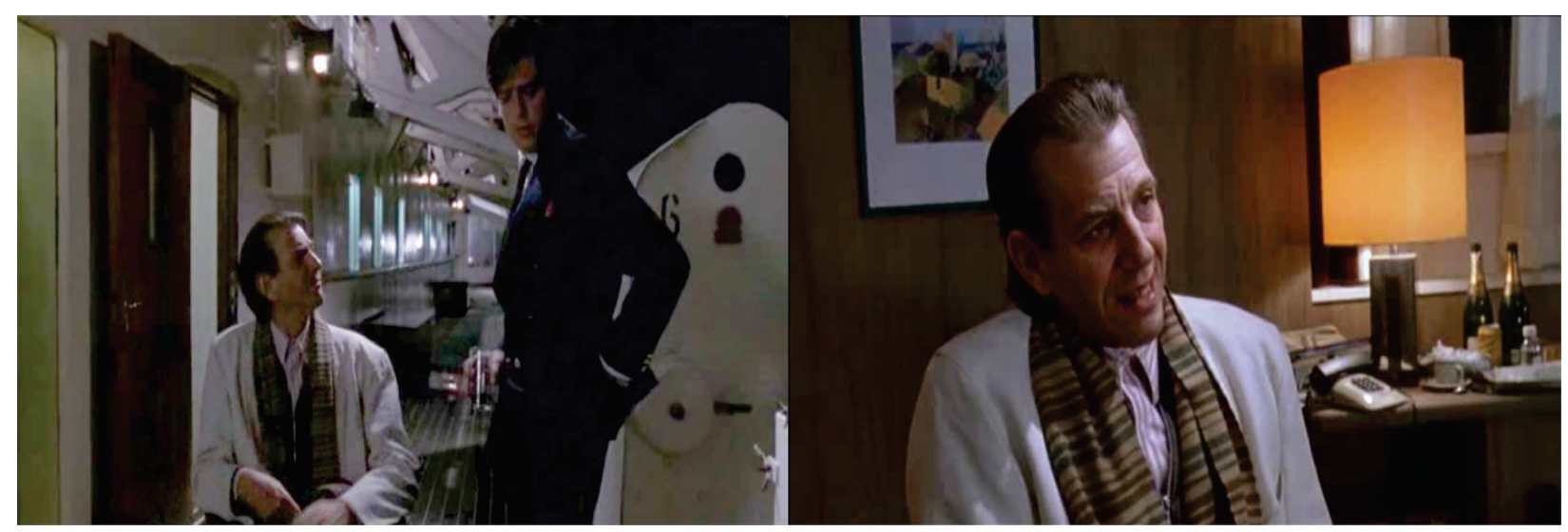

Figura 3 - Primeiro encontro de Nigel com Oscar. Início da erótica e atraente narrativa. Fonte: frames extraídos do filme Lua de Fel(1992) pelos autores.

você quer trepar com ela, isso não é crime" (LUA, 1992). Ou seja, o sádico marido atiça, induz, conduz o boneco manipulável, agora em suas mãos. Este nada malicioso deixa-se levar, está totalmente atraído pela jovem e quer descobrir como chegar à mulher desejada.

O enredo é drama psicológico, no qual as fraquezas, baixa-estima, inseguranças, fantasias, desejos reprimidos, sadismo, prazeres insondáveis vêm à tona e desmascaram aparências. Para Oscar, fantasias, prazeres têm de ser vividos ao extremo, sem limites ${ }^{5}$. É com tom natural, arrogante, debochado, irônico que desafia Nigel a ouvir toda a história, contada detalhadamente, num misto de prazer e sordidez. Espaço e ocasião aproximam seres distintos, quanto aos cuidados de si e ao modo de ser e viver, um expõe-se demais, outro tenta esconder-se. Nigel se deixa envolver no clima erótico imposto às palavras do sádico marido da Mimi. Georges Bataille ajuda a entender o torpor do recatado inglês, pois que:

O erotismo é, na minha opinião, o desequilíbrio no qual o ser a si próprio se põe em questão, conscientemente. Num certo sentido, o ser perde-se objetivamente, mas nesse caso o sujeito identifica-se com o objeto que se perde. Se for necessário, posso dizer no erotismo: Eu perco-me. Não é esta, certamente uma situação privilegiada, mas o que se não pode negar é que a perda voluntária implicada pelo erotismo é flagrante (BATAILLE, 1988, P. 27).

Oscar desestrutura, flagra, desequilibra a estabilidade de Nigel. Desequilíbrio condizente com seu estilo moderado de ser. Ao desejar outra mulher, Nigel se perde no próprio querer. Ambos têm em comum, fantasias sexuais, vividas ou sonhadas, embora Nigel não admitisse, ele estava prestes a passar do estado latente para a assunção dos desejos. O que naturalmente, o desnorteou. Mas, mesmo negando, ou desorientado, entra por inteiro no que supôs ser uma nova relação amorosa. Assim, Nigel encontra-se no erotismo do coração e Oscar no erotismo do corpo, numa referência apressada às formas distintas de erotismo, propostas por Bataille.

Oscar tem o dom das palavras, começa a narrar a paixão incontrolável que viveu, não esconde minúcias, percebe o quanto esses pormenores excitam Nigel. Este imagina e "vive" esses momentos revelados pelo incitante narrador. Ele poderia interromper esses encontros, mas não. Nigel recrimina o modo de falar do Oscar, mas retorna para ouvi-lo, já dependente do clima criado e da promessa que possuiria Mimi, após ouvir o relato completo. Assim, ele, a cada encontro, sentese mais perturbado, e não consegue desvencilharse do interesse pela história do casal. Quer a Mimi.

E tudo começou assim: num transporte coletivo, uma bela jovem não tem bilhete, o desconhecido passa o dele para evitar constrangimento a ela. Ela desce, ele, encantado com tal formosura, fica a observá-la, meio atordoado pela beleza da jovem desconhecida. Obcecado pela imagem fulgurante da passageira do ônibus, o rico escritor, passa os dias à espera, até encontrá-la novamente.

Oscar, sedutor, envolve e deixa-se envolver, como se nada mais existisse, somente os dois! 


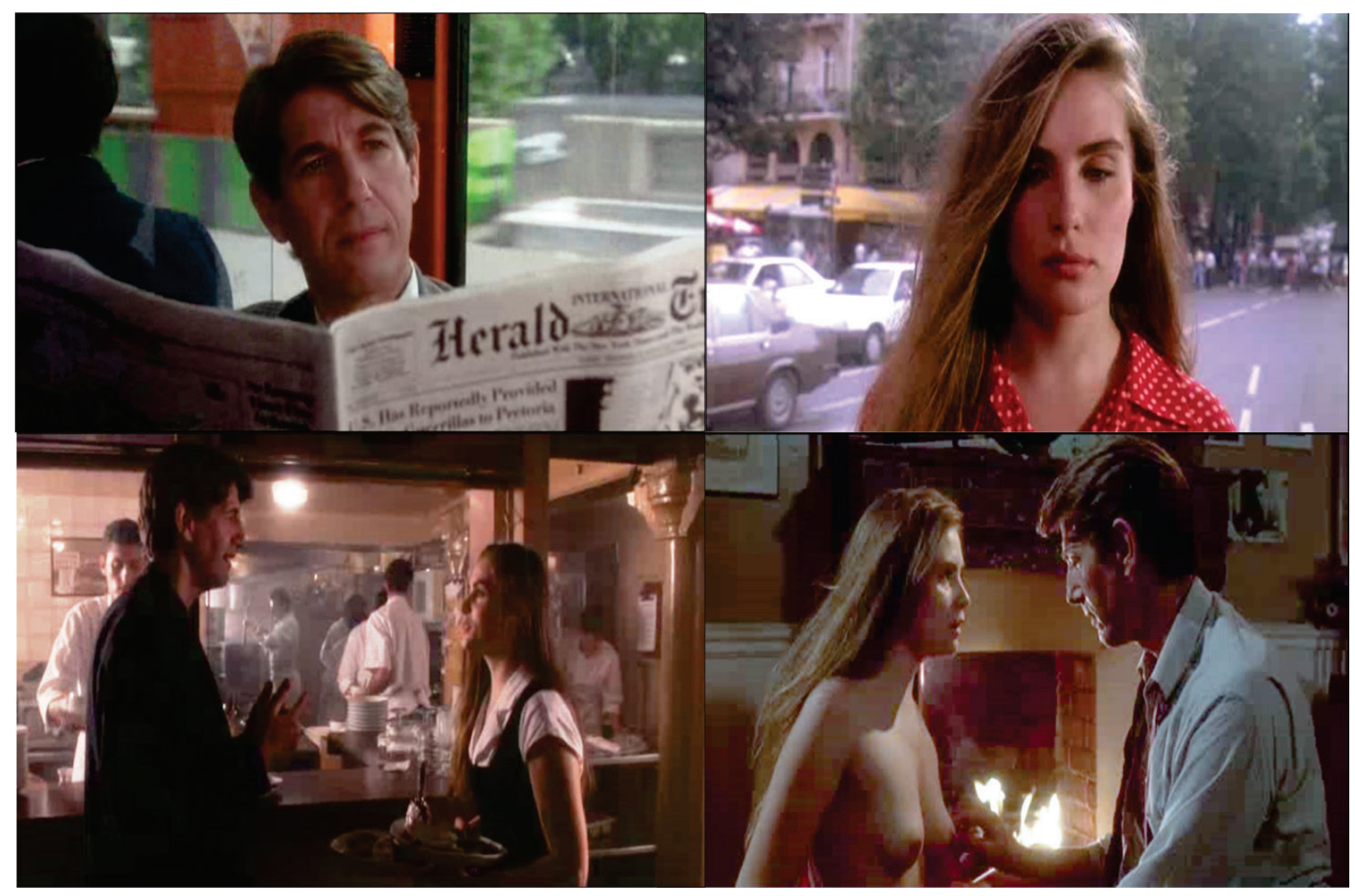

Figura 4 - O encanto dos primeiros encontros. Fonte: frames extraídos do filme Lua de Fel (1992) pelos autores.

Escritor, embora frustrado, sabe enfeitar o que faz e narra de maneira poeticamente sarcástica as suas aventuras amorosas. Todas e, principalmente, a vivida com Mimi. Herdeiro de fortuna foi morar em Paris, disposto a seguir os passos de Hemingway, Miller, Scott Fitzgerald, talvez por identificação com suas histórias e desejos expressos em suas obras; publica somente três romances e busca compensações com casos furtivos, noitadas de festas.

Oscar promete, se você ouvir a história toda, terá Mimi. Nigel aceita ser o ouvinte. E assim começa a narração com flashbacks ${ }^{6}$. Diz Oscar:

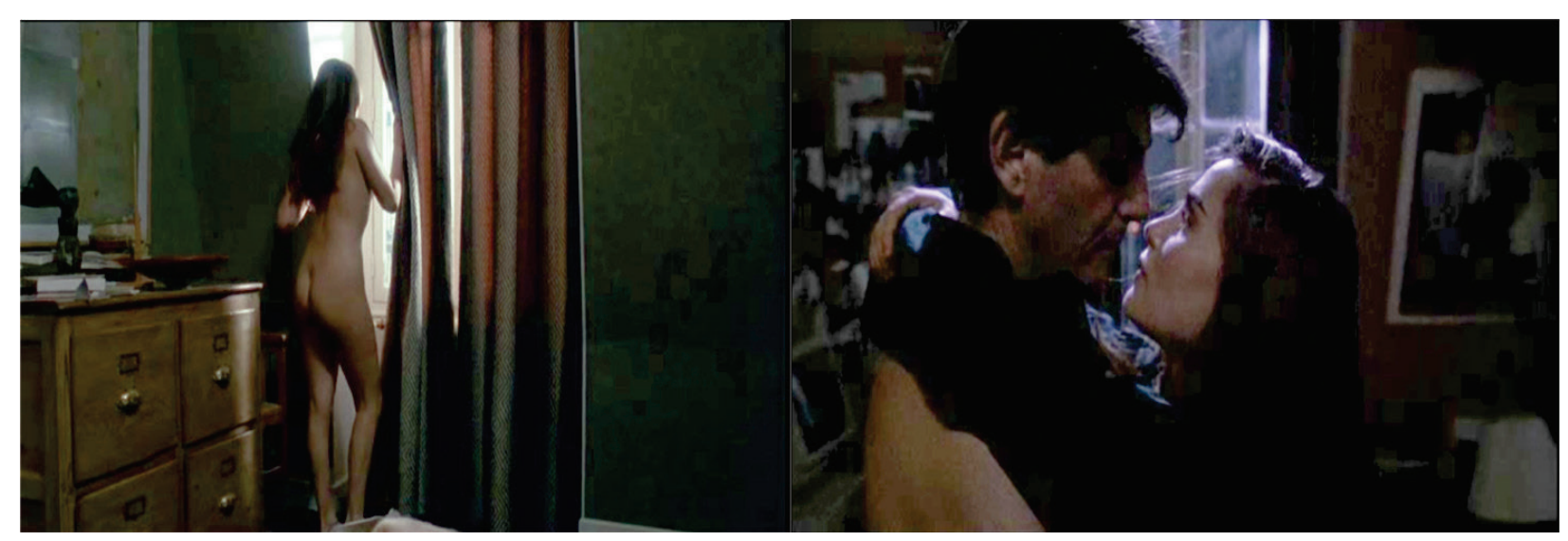

Figura 5 - Primeira noite de Oscar e Mimi. Fonte: frames extraídos do filme Lua de Fel (1992) pelos autores. 


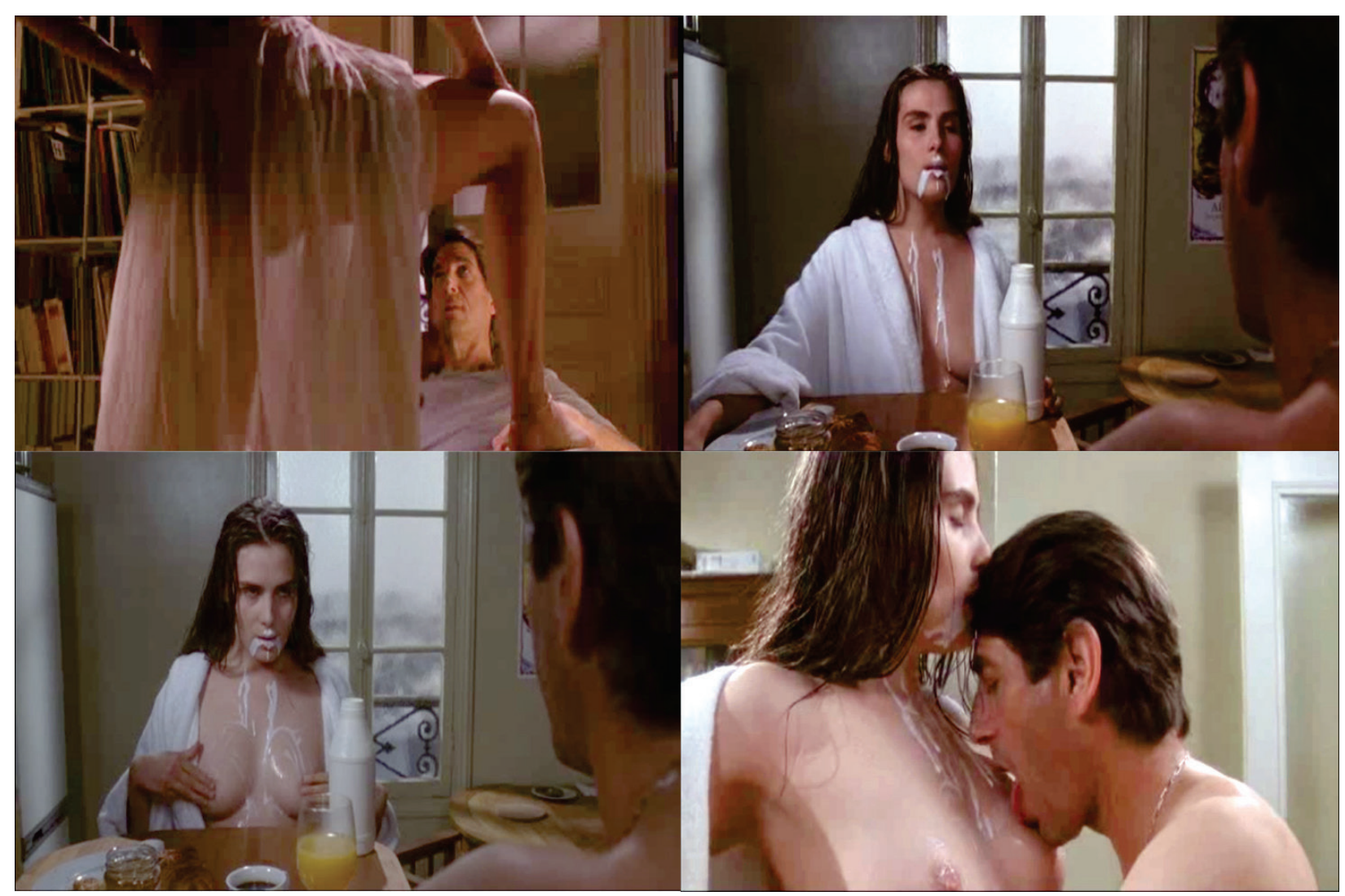

Figura 6 - Amor e sexo: descobertas, revelações. Fonte: frames extraídos do filme Lua de Fel (1992) pelos autores.

"a eternidade para mim, começou um dia em Paris, no ônibus 96, trajeto entre Montparnasse e Porto des Lilas" (LUA, 1992). Ao vê-la, vislumbrara o paraíso. A reencontra mais tarde como garçonete, marcam jantar e, desse dia em diante, confinam-se em casa, para viver o amor intenso. Mimi exalava frescor e inocência, misto de maturidade sexual e ingenuidade, o que tocou o coração do boêmio. Ele, o experiente, dono da situação, conduz o romance ao seu modo. Isolados de todos, vivem paixão intensa, esquecidos de que o desejo e o corpo têm limites e que não há necessidade de esgotarem-se em entrega ininterrupta.

Após exaustivas sessões eróticas, ele lê para ela. Ela encantada, diz que o escutaria para sempre. Polanski capta nessa cena a força erótica e passional de duas personagens a desnudarem um ao outro, confiantes no vindouro?. Eles vivem um tipo de amor muito particular, aliás, em assuntos de amor, Paulo Leminski foi certeiro ou provocador. Afirma o poeta paranaense que amor entre pessoas se coloca na "ordem do mistério":
Existe realmente alguma coisa, um clique que só quem já sentiu sabe. 0 amor é uma anomalia engraçada. (...) não existe nenhuma, nenhuma disciplina científica que tenha o amor como objeto. (...) O amor é uma coisa que você vai ter que procurar nos artistas, na televisão, no cinema e, principalmente, na poesia. (...) Saber como o amor nasce, a primeira paixão, o amor à primeira vista, a continuação da paixão, o fim do amor, isso eles teriam que ir buscar nos poetas. (Paulo Leminski). ${ }^{8}$

Tudo parecia perfeito, até que, primeiros indícios de sadismo entram em cena. Ele fazendo a barba, ela pede para barbeá-lo. Ele, mesmo com receio, permite. Ela o fere. Aí, o olhar dela para a dor do companheiro, indica, contradiz a inocência que passava, deixa no ar algo de prazer pela dor do outro.

Para espanto de Nigel, Oscar apimenta o relato, "sua vagina era uma pequena fenda, discreta e pura, mas quando excitada por ele, o animal dentro dela (;) ela afastava a cortina de seda que cobria sua toca" (LUA, 1992). A fisionomia de 


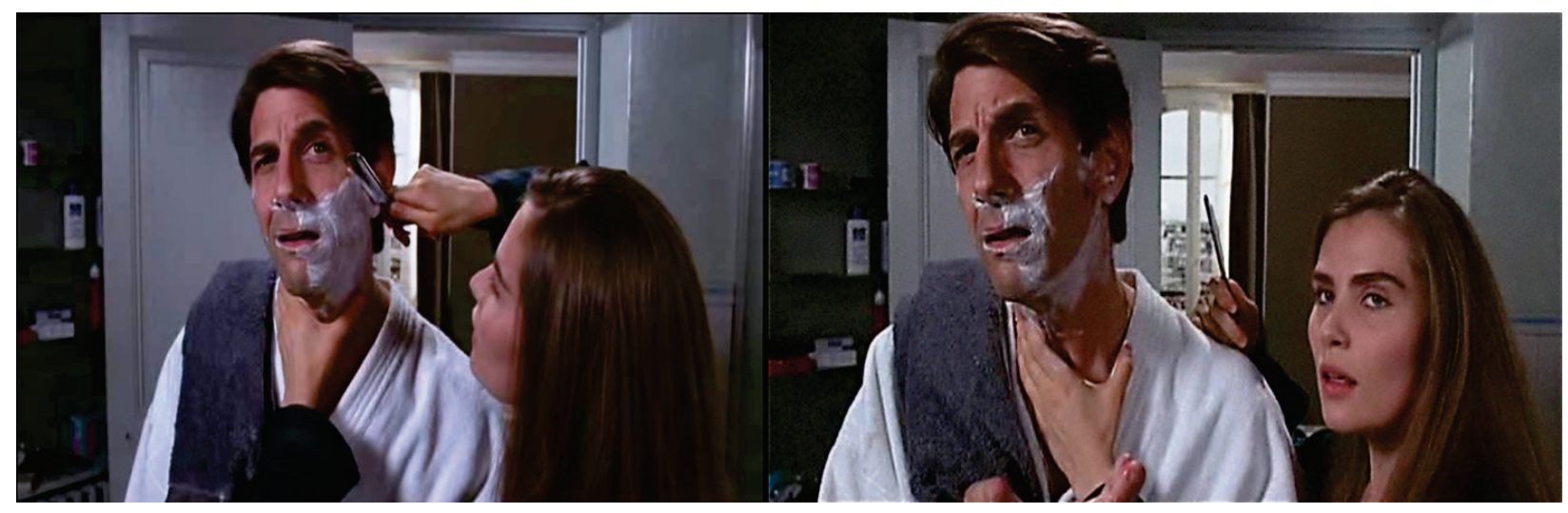

Figura 7 - Mimi demonstra estranheza e prazer pela dor em Oscar. Fonte: frames extraídos do filme Lua de Fel(1992) pelos autores.

Oscar, enquanto conta, é de quem se vangloria e diverte-se com o horror estampado na face e no corpo tenso de Nigel. E justifica, "só dou detalhes para mostrar como estava escravizado de corpo e alma por essa criatura, cujos encantos o impressionaram" (LUA, 1992). Nigel disfarça sua repugnância e, com paciência de analista, ou seria o interesse de voyer, imagina, vê o que é narrado, excita-se. Tais cenas aumentam seu desejo por Mimi.

Esta, o encontra nos corredores do navio e diz para ele não acreditar em tudo que Oscar conta, contesta a história e diz: "Nigel, não faça mal juízo sobre mim" (LUA, 1992). Oscar alfineta, para diminuir o rival e afirma que "Mimi se contenta com menos, do contrário, não teria se casado comigo" (LUA, 1992). A Mimi é encantadora, mas Fiona tem aquela beleza britânica sutil, reticências que sugerem potencialidades não exploradas por ela ou por Nigel. Todos têm seus ângulos secretos. E insiste, "toda relação, mesmo harmoniosa, contém sementes de farsa ou de tragédia" (LUA, 1992). Outro contraste entre os dois, Nigel quer que o tempo continue bom, Oscar quer que o navio afunde, para ficarem em ilha deserta. Humor negro a ferir os demais, o tempo todo.

Oscar continua o relato. Passada a fase empolgante, veio a saturação do desejo, a indiferença, o desprezo. A relação passa a ser de sado-masoquismo assumido por ele, sentiase muito bem com ela humilhada a seus pés. Ela continuava a dizer que o amava. Oscar, assim que consegue subjugá-la, perde o interesse. Ele relembra "antes ela era meu Nilo, meu Ganges, minha fonte de juventude. Meu segundo batismo. Não fique horrorizado Nigel, estou expandindo teus horizontes sexuais. Você com Fiona deve ter transas adequadas, sanitárias, higiênicas" (LUA, 1992). Ao que Nigel defende, "pelo menos temos alguma decência. Esses detalhes sórdidos são obscenos" (LUA, 1992). "Obsceno? Você já sentiu paixão verdadeira, dominadora? Já idolatrou uma mulher? Nada é obsceno num amor assim. Tudo que ocorre se torna um sacramento" (LUA, 1992).

Após esse período de paixão intensa, apelam para acessórios e jogos eróticos mascarados para manter a chama do desejo. Extravasam todas as fantasias, humilhar, bater, sofrer, provocar sofrimento, sadicamente, tudo vale. Mas todas as brincadeiras esvaziaram-se, o desejo esfriou. O sadismo dele aflora, divertese em fazer com que Mimi sinta-se feia. 0 golpe decisivo de Oscar foi quando Mimi contou que estava grávida e ele a convenceu a abortar, prometeu viagem para os dois e a despachou sozinha para Martinica. Crueldade, medo, receio de ficar preso ao amor? Ele volta às noitadas, procurando ser/ter o que era/tinha antes do amor doentio por Mimi. Até sofrer um acidente que o deixou imobilizado.

Mimi aparece para visitá-lo, diálogo amargo, irônico. Aí começa a vingança, inverte-se a posição de quem tem poder. Mimi o derruba do leito do hospital. A convalescença torna-se martírio, fica paraplégico e ela cuidará dele. Ele não tem como rejeitar. Agora ela tem o controle, domina e sente prazer nisso. Nessa situação, casam-se e consolidam a dependência, um 


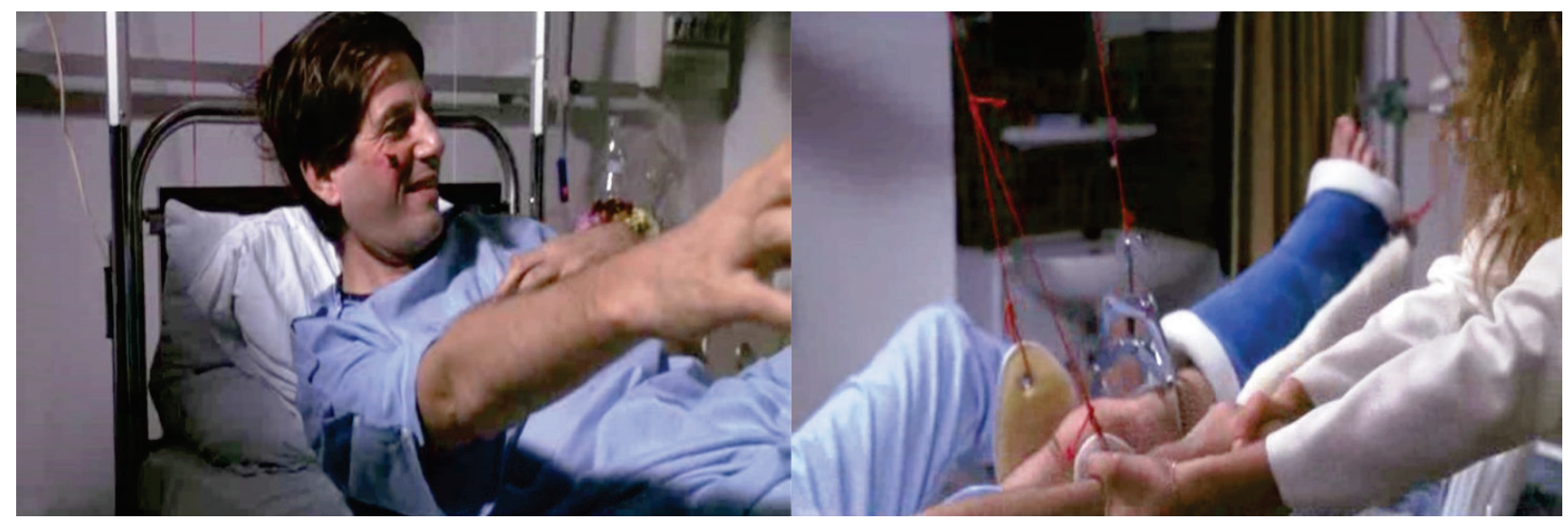

Figura 8 - Cena em que Mimi visita Oscar, provoca a queda que o deixará impotente e sob o controle dela.

Fonte: frames extraídos do filme Lua de Fel (1992) pelos autores.

ligado ao outro pelo sentimento de desprezo, sadismo, hostilidade e algo mais que fica em aberto, cada espectador deduzirá que sentimento haveria a mais entre o casal. É nesse clima perverso, que os casais se encontraram no cruzeiro que os levaria à Índia. Polanski registra estas personagens sem maniqueísmos. Ambos decidiram que assim seria sua relação, até o fim. ${ }^{9}$

Oscar, após o acidente, tornou-se uma espécie de voyer. O homem, antes afoito, adepto de todos os jogos eróticos, ao ver Mimi dançando, indo para a cama com outro homem, demonstra insatisfação, despeito, certo asco talvez. Nessa cena, ele não era o protagonista, o garanhão. Olhar somente, não basta a quem fora o conquistador aventureiro. Na relação com Mimi, o que pareceu ser a inteireza do amor, talvez absoluto, tornou-se outra mistura de sentimentos confusos, rancor, vingança, ódio, decepção, dor pelo desgaste da paixão

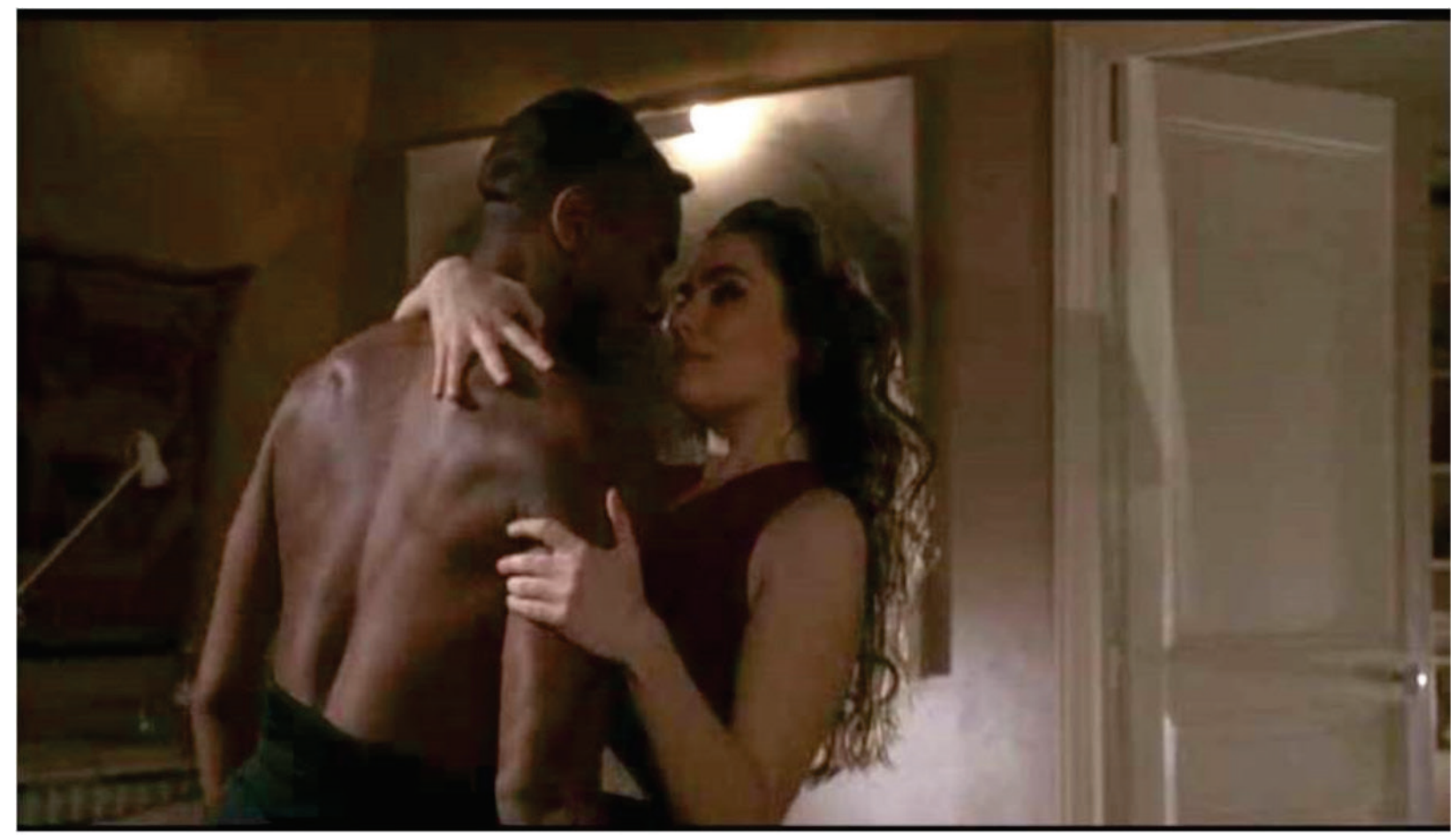

Figura 9 - Mimi com dançarino sob olhar de Oscar . Fonte: frames extraídos do filme Lua de Fel (1992) pelos autores. 


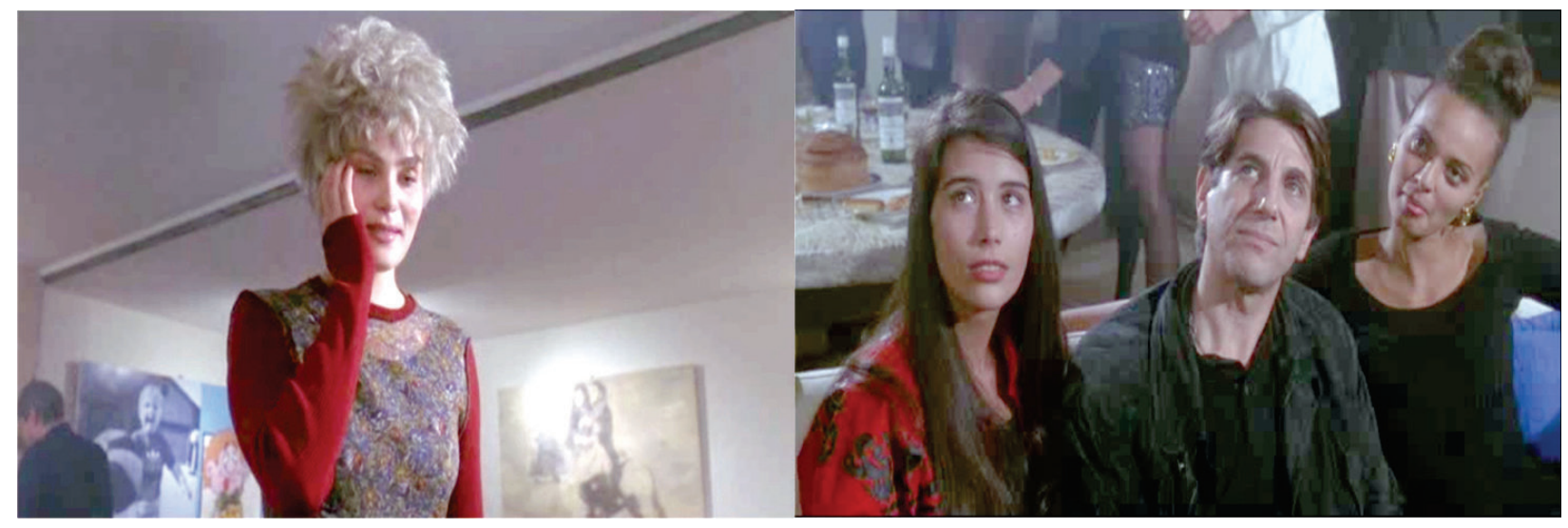

Figura 10 - Oscar ridiculariza e despreza Mimi.

Fonte: frames extraídos do filme Lua de Fel(1992) pelos autores.

avassaladora e, quem sabe, até resquícios do amor vivido tão intensamente.

Pronto, situação perfeita para que o romântico Nigel se convencesse de que poderá tirá-la de tal tormento. Isso incentiva Nigel a ouvir e conhecer toda a história. Durante os encontros da narração, Mimi, sedutoramente, aparecia de surpresa, com ar de moça boazinha à espera de um príncipe apaixonado. Quanto à esposa, Fiona, desde o início, percebeu o interesse do marido pela jovem. No entanto, fina, sutil, educada, fala ao marido que já percebeu o interesse dele, mas mantém-se discreta e distante. Como, se no fundo, esperasse por algo dessa natureza, ou seja, que o marido desse motivo para que ela também externasse desejos guardados. A liberação dos desejos de Nigel serviria para que ela também liberasse os seus. Enquanto, Fiona mantém-se no papel da esposa omissa, recatada, elegante, Mimi, por ser diferente dela, ganha espaço, domina as reações e o coração do pseudo-ingênuo Nigel.

Oscar afirma que Mimi tem razão em procurar o que ele já não pode dar, mas que ele avalia quem fica com ela. Ele precisa manter seu domínio. "Você pode tê-la com minha bênção, mas com uma condição. Ouvir-me, tenha compaixão, não seja duro com um homem destruído por um amor intenso. Sim, devíamos ter terminado ali. Os casais deviam se separar no auge da paixão e não esperar até o inevitável declínio" (LUA, 1992).

A beleza de Mimi não mais o excitava, nada significava para ele. Ambos dependentes da televisão ou algo que os mantivessem próximos apesar de indiferentes um ao outro. A televisão, segundo Oscar, "permite que os casais se aturem sem ter de conversar" (LUA, 1992). Todos os hábitos que antes o encantavam, agora o irritam, como beber leite na garrafa. Ele volta à vida promíscua, numa tentativa de busca desesperada pela vida descompromissada, livre, antes de conhecer Mimi. Ela aceita todo tipo de condição imposta por ele. Ele ainda insiste para que ela volte às aulas de dança, ela diz que se dança com o coração e o dela está quebrado. Ele propõe separação, "preservemos uma bela recordação" (LUA, 1992). Ela quer dedicar o resto da vida dela a ele; ele: "não quero o resto da tua vida, quero a minha" (LUA, 1992).

Após ouvir toda a história, Nigel diz entendê-los melhor, sai disposto a acabar o casamento com Fiona, ensaia falas. O desejo o (des)controla. Nada mais o limita. Religião, valores, ética, moral e toda uma pedagogia de repressão de suas vontades. Nenhum elemento de controle detém Nigel neste momento ${ }^{10}$. Ele volta ao quarto, Fiona dorme. Antes, Fiona o advertira, "cuidado Nigel, o que quer que faça, posso fazer melhor" (LUA, 1992). E fez!

E o desfecho acontece na festa de ano novo. Nigel deixa a esposa dormindo e desce, todo galante. Bebe e toma coragem para dançar com Mimi. Quando se declara apaixonado por Mimi, esta diz que nunca será dele, "sou só uma fantasia para distrair uma viagem enfadonha" (LUA, 1992). Enquanto fica nesse enlevo, Oscar manda acordar Fiona. Esta desce, belamente vestida e presencia o marido a seduzir Mimi. 


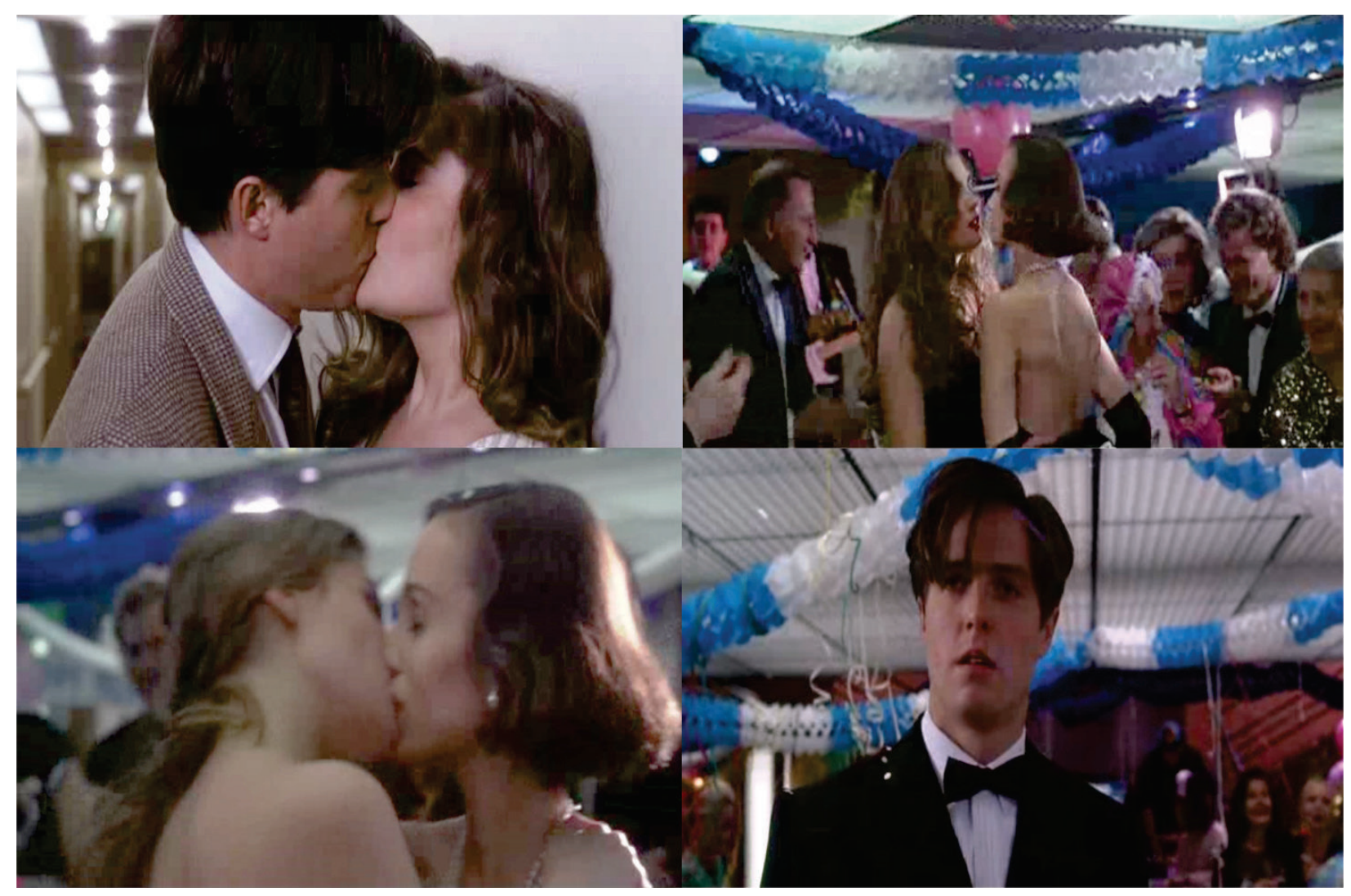

Figura 11 - Nigel finalmente se entrega aos desejos por Mimi, e sua esposa também. Fonte: frames extraídos do filme Lua de Fel(1992) pelos autores.

Ao ser elogiada pelo marido, afirma "sintome perigosa, hoje" (LUA, 1992). Oscar: "Esse é o espírito, Fiona!" (LUA, 1992). Oscar poderia afirmar que ser normal é a meta fracos e medrosos, dos que não experimentam nada, além do considerado correto. Pois bem, aí vem o elemento surpresa, não para Oscar, este já percebera os mistérios escondidos na beleza de Fiona. Ela vai até a pista, começa a dançar com Mimi. Num clima arrojado, beijam-se para espanto de todos. Oscar vibra, Nigel fica a ver navio, literalmente.

Significativamente, o mar agita-se, o navio balança, os convidados vomitam, caem, as duas vão para o quarto. Oscar assiste a cena em que as duas mulheres fazem amor. Nigel vai à procura da mulher, se depara com a cena. Oscar ironiza, "já viu tal alegoria de graça e beleza? Duas ninfas dormindo depois de fazerem amor. Fiona foi uma revelação! Ela é fogosa!" (LUA, 1992). Nigel reage, quer estrangulá-lo, ele aponta a arma, Nigel recua. Oscar atira em Mimi e diz, "fomos gananciosos demais, baby" (LUA, 1992), em seguida, aponta o revolver para a própria boca e aperta o gatilho.
É o fim de Mimi. Libertação de Oscar? Renascimento de Fiona e Nigel? Certamente, temos reticências plantadas por Polanski neste trágico final compatível, talvez, com o comportamento transgressivo dos casais. Para Bataille "a transgressão da proibição está tão sujeita a regras quanto a própria proibição. Não se trata de liberdade: em determinado momento e até determinado ponto, esta coisa é possível. Eis o sentido da transgressão" (BATAILLE, 1988, p. 57). Eis o sentido da relação de Mimi e Oscar, foram longe demais. Quanto ao casal sobrevivente, eles vivenciam uma espécie de convulsão interna, saem dessa aventura, transformados pela digressão, invasão do outro, ambos cedem aos desejos, ele de maneira, aparentemente romântica. Ela, para vingar-se do marido ou, quem sabe, para satisfazer desejo acalentado por estar com outra mulher. Aliás, ela já o tinha alertado de que poderia fazer bem melhor. Não sabemos se tal experiência os unirá mais ou os separará, não importa. O que importa é que, retomando a epígrafe de Bataille, ambos quebraram correntes, ousaram, protagonizaram outras cenas. 


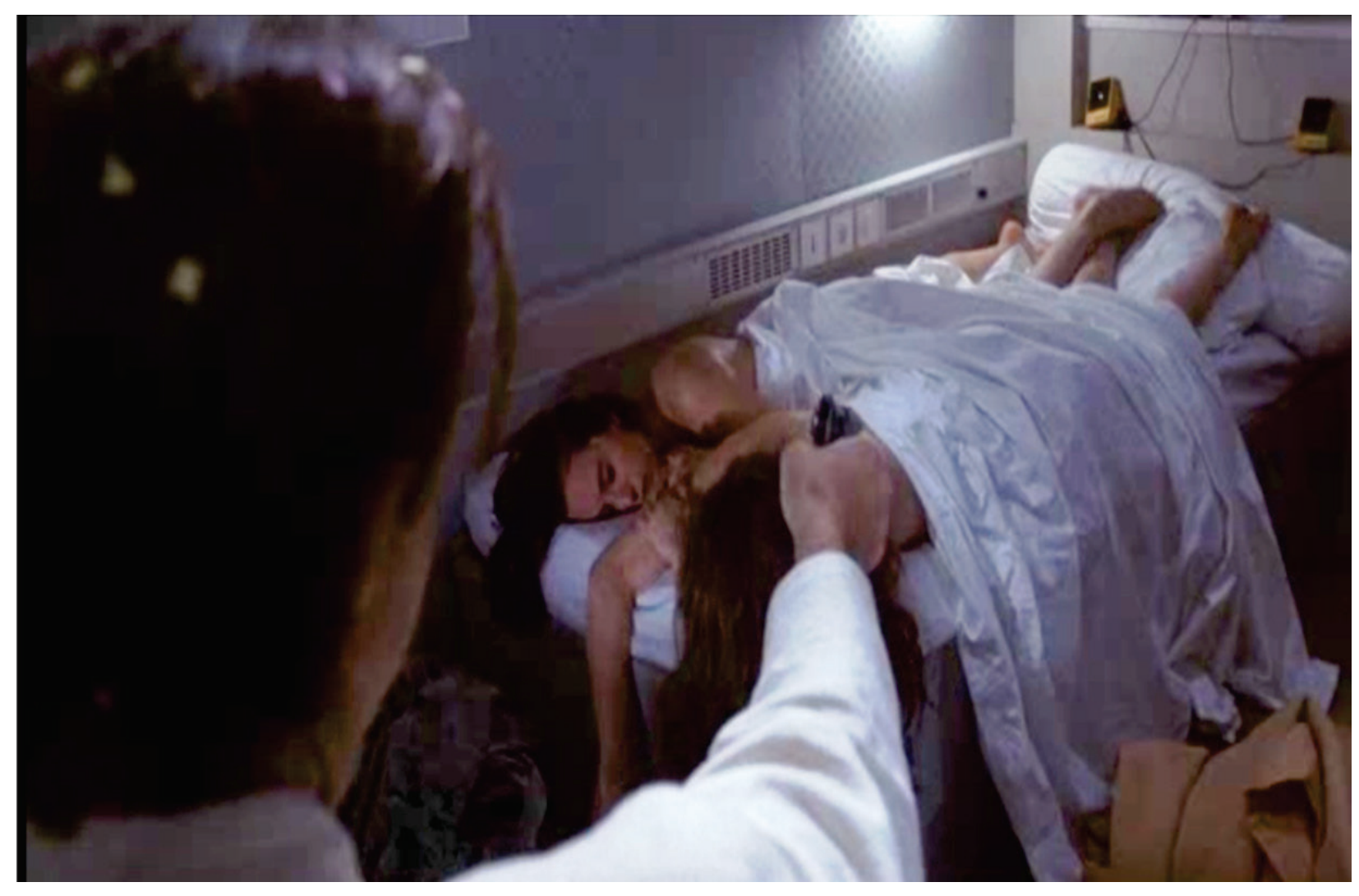

Figura 12 - Trágico final. Fonte: frames extraídos do filme Lua de Fel(1992) pelos autores.

Diríamos que o casal talvez tenha chegado próximo à certeza, após dúvidas e fantasias, parafraseando Wislawa Szymborska, de que aquilo que é importante, é mais importante do que aquilo que não é. Ou seja, dar vazão e experimentar fantasias, não precisa significar o rompimento de união estável. No caso deste filme, após o trágico desfecho, ambos, aterrorizados e, silenciosamente, abraçam-se. Ambos a necessitar do cúmplice amparo para superar tal desventura. A filha do indiano interrompe o casal para desejar Feliz Ano Novo! O indiano havia alertado o casal de que não precisavam procurar nada na Índia. É como se afirmasse, o que vocês procuram está entranhado em vocês, não será dado por outrem ou por lugares escolhidos, mas é fundamental a busca de si mesmo, sob o testemunho da lua ou não, que aparece em destaque no último plano do filme, como a referência poética de possível renovação para Nigel e Fiona.

Lua de Fel (1992) dividiu a crítica internacional. Afinal, o erotismo nem sempre é bem desenvolvido em diversas visões cinematográficas. Muitos filmes abordaram esse tema de forma pejorativa, preconceituosa e comercial. Afinal, erotismo e sexo são assuntos evitados por muitos. E, ao não valorizar tal assunto, ideias toscas são mantidas, numa sociedade constantemente impregnada de mecanismos controladores, a fim manter a repressão e conceitos arcaicos aos indivíduos que a compõem. Erotismo e sexo estimulam fantasias não controláveis ou limitadas por decretos. $\mathrm{E}$, um indivíduo que vive sem limites, quebra barreiras, confronta valores, enfim, transgride, é sempre perigoso, pois vive a vida de maneira mais livre e debochadamente provocadora.

Carlos Gerbase acredita que os filmes que flertam com as representações do sexo, pornográficas ou não, podem trazer algo de libertário, em certo sentido:

Libertário é todo filme que representa o sexo com embriaguez, que respeita o caráter transcendente do erotismo, que consegue registrar os movimentos dos corpos na busca dos adornos estéticos que permitem uma relação amorosa mais duradoura depois de esgotados os momentos de paixão febril e animal. É libertário o filme que consegue escapar do jugo mercadológico e propor 


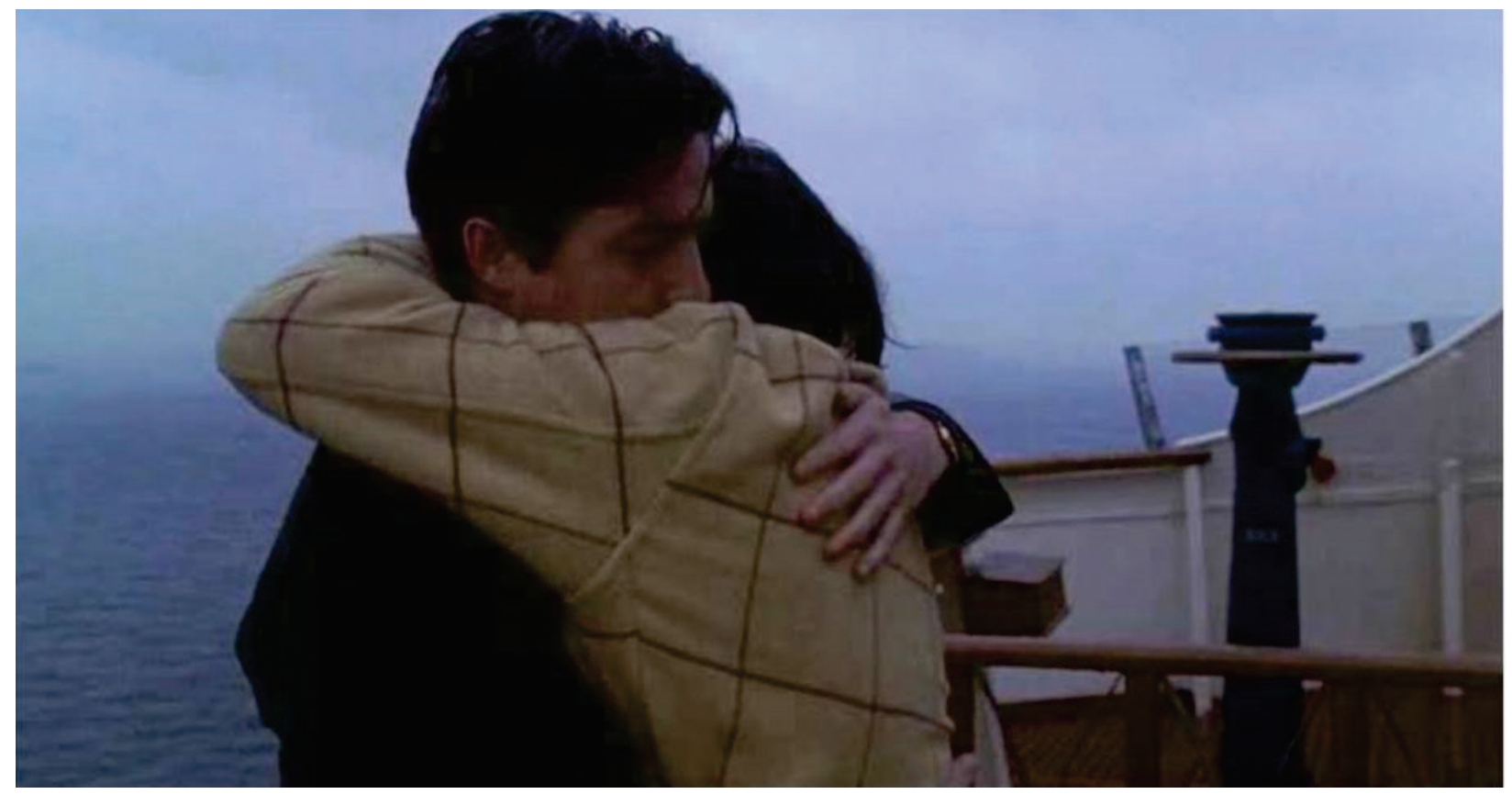

Figura 13 - Possível recomeço? Fonte: frames extraídos do filme Lua de Fel (1992) pelos autores.

ao espectador numa narrativa que contém um viso pessoal, subjetiva e apaixonada do cineasta pela história e pelas suas personagens. Também é libertário o filme que retira a mulher de sua condição de subserviência ao homem, tradicional em Hollyvood (GERBASE). ${ }^{11}$

O cinema de Polanski soube lidar com esse tema, direta ou indiretamente, como em Repulsa ao Sexo (1965), A Dança dos Vampiros (1967) ou Tess (1979) e, posteriormente, em $A$ Pele de Vênus (2013). Em Lua de Fel (1992), Polanski abordou o tema delicado, cuja trama provoca nossa imersão em conceitos de moral, desejos, valores que aprisionam o indivíduo. Este filme compõe o mosaico de sua obra, no sentido de contar histórias com personagens ousadas que, por vezes, não têm percepção do quanto são capazes para realizar desejos e fantasias erótico-amororas. Tais pessoas-personas, ao depararem-se com situações inusitadas, incitantes, podem se descobrir e mudar suas vidas. Mesmo que a mudança seja provisória, passageira, momentânea. Polanski poderia concordar com o cineasta italiano Pier Paolo Pasolini, "Quando faço um filme, ponho-me em estado de fascinação diante de um objeto, de uma coisa, de um rosto, dos olhares, de uma paisagem como se tratasse de um engenho onde o sagrado estivesse na iminência de explodir". (PASOLINI). ${ }^{12}$
Assim, o casal Oscar e Mimi, extrapolam regras, ignoram limites, entregam-se aos jogos eróticos, talvez tenham esquecido de que a exaustão pode ser prejudicial, se não acompanhada de sentimentos mais duradouros. Nesse clima de insinuações e sedução é que Nigel e Fiona, ao serem in(ex)citados, testam limites da relação estável. Polanski e Pascal Bruckner, ao provocarem tais situações, demonstram que escolhas têm preço e consequências. Lua de Fel (1992), à época de seu lançamento, foi considerado, por alguns críticos e parte do público, um filme estereotipado devido às personagens e à trama. O final pode parecer moralista, já que Mimi morre, Oscar morre, Fiona e Nigel reaproximam-se. Se ficarão juntos ou não, não importa, o fato é que ambos saem dessa aventura modificados. A amargura e melancolia com que o diretor constrói a narrativa do filme, nos levam a outras interpretações e reflexões que ultrapassam qualquer julgamento moral.

Lua de Fel (1992) é um filme amoral e nos confronta com a falácia de valores embasados no falso moralismo, além de mostrar inerentes contradições humanas para perceber/ entender tal complexidade e possibilidades outras de mudanças, no que se refere a relações erótico-amorosas. Afinal, amar/desejar pode 
transformar-se em ato arriscado. É um filme sobre conflitos existenciais que leva o espectador a uma trajetória sobre a paixão, o sexo, o voyerismo, o desejo, os meandros do inconsciente. E nesse jogo ousado, para as personagens e espectadores, tudo pode ser vivido. Sem medos. Senão, nada valerá. $E$, envolvidos pela força erótico-poética do filme, citamos a escritora Clarice Lispector:

Não quero formar a vida porque a existência já existe. Existe como um chão onde nós todos avançamos. Sem uma palavra de amor. Sem uma palavra. Mas teu prazer entende o meu. Nós somos fortes e nós comemos. Pão é amor entre estranhos (LISPECTOR, 1991, p. 57).

Oscar e Mimi ao comungarem dos próprios corpos, desejos, fantasias, talvez tenham esquecido de que falar, realizar fantasias não basta, há que haver entendimento e concordância para obterem prazeres mútuos. A eles, faltou tal cumplicidade!

\section{NOTAS}

01. Roman Polanski (1933-) é ator, diretor, roteirista e produtor nascido na França. Iniciou sua carreira no cinema polonês com elogiada estreia em Faca na Água (1962). Na França, dirigiu seu primeiro trabalho polêmico, Repulsa ao Sexo (1965). Em 1968, foi para Hollywood e realizou um dos maiores sucessos da sua carreira, O Bebê de Rosemary. Seus filmes têm personagens que se relacionam com sua vida particular que teve diversos problemas como o assassinato de sua esposa Sharon Tate quando deixou a Polônia para realizar seus trabalhos na França e posteriormente nos Estados Unidos.

02. A adaptação cinematográfica do livro foi realizada por Polanski, Gerald Brach e John Brownjohn. Brach (1927-2006) foi um roteirista francês e trabalhou com Polanski em diversos filmes como Repulsa ao Sexo e 0 Inquilino. Um de seus melhores trabalhos é a adaptação cinematográfica de 0 Nome da Rosa, de Umberto Eco.

03. O ator Hugh Grant que interpreta o papel de Nigel realizou até o período das filmagens de Lua de Fel(1992) vários filmes com personagens considerados de bom caráter e prestativos (um bom moço). Kristin Scott Thomas que interpreta Fiona tem uma beleza clássica que a define como uma espécie de "princesa intocável" que reprime e controla seus desejos. Peter Coyote que faz o papel de Oscar surge como um americano de meia idade frágil e carente e Emanuelle Seigner (esposa do diretor) é a catalisadora de todo o processo de desejo e sedução entre todas as personagens principais. Polanski é discreto e atrevido ao filmar o corpo de Seigner direcionando sua câmera para seus olhos e gestos que conquistam e depois repelem Oscar e Nigel.

04. A Índia foi retratada, várias vezes, no cinema como um lugar exótico, oposta ao mecanismo da cultura capitalista e lugar perfeito para o encontro de outras identidades. Por esse estereótipo, é interessante notar que Polanski evidencia que o lugar é "barulhento" e que muitas vezes se procura ali o que está dentro de cada um.

05. Polanski em Repulsa ao Sexo (1966) mostrou a vida de uma mulher que é sexualmente reprimida e resiste aos assédios do seu namorado. Com tanta repressão, a personagem se "liberta" através de alucinações. Nigel, inicialmente, se liberta através da história contada por Oscar e, depois, tentará consumar seu desejo.

06. Flashback é um recurso da linguagem cinematográfica que revela acontecimentos que passaram na vida de uma personagem e são relevantes durante a narrativa. Aqui, acompanharemos a história de Oscar e Mimi pelas lembranças e re-elaborações de Oscar.

07. Polanski filma a atriz Emmanuelle Seigner (sua esposa) com destaque para seu corpo, mas capta especialmente seu olhar nos momentos mais sensuais com Oscar ou Nigel. Ele repete aqui a mesma forma de observação ao corpo feminino que tinha revelado em Repulsa ao Sexo (com Catherine Deneauve), A Dança dos Vampiros (com Sharon Tate), Chinatown (com Faye Dunaway) e Tess (com Nastassja Kinski).

08. In: CARDOSO, Sergio et al. Os sentidos da paixão. São Paulo: Companhia das Letras, 1987. (p. 292-293).

09. Roman Polanski é um diretor que trabalha com muita eficiência os elementos da linguagem 
cinematográfica. Sob sua orientação, o diretor de fotografia Tonino Delli Colli (que iniciou sua carreira no cinema em 1938) não exagera na iluminação e cores para as cenas de Oscar e Mimi ficarem mais naturais, humanas, simples. A trilha sonora, composta pelo compositor grego Vangelis (autor das trilhas de Blade Runnere 1492), possui um tema romântico e melancólico que acompanha diversas cenas e insere maior envolvimento do espectador à narrativa do filme.

10. A cena foca especialmente o rosto do personagem vivido por Hugh Grant para demonstrar sua volúpia e atração sexual por Mimi.

11. In: Cinema explícito. Representações cinematográficas do sexo, de Rodrigo Gerace.

12. In: Os sentidos da Paixão, de Sérgio Cardoso.

\section{REFERÊNCIAS}

BATAILLE, Georges. Erotismo. Belo Horizonte: Autêntica, 2014.

LEMINSKI, Paulo. In: CARDOSO, Sergio. Os sentidos da paixão. São Paulo: Companhia das Letras, 1987.

LISPECTOR, Clarice. Laços de família. Rio de Janeiro: Francisco Alves, 1991.

Lua de Fel. Direção: Roman Polanski. Produção: Robert Benmussa, Roman Polanski. Roteiro: Gerald Brach, John Brownjohn, Roman Polanski. Intérpretes: Emmanuelle Seigner, Hugh Grant, Kristin Scott Thomas, Peter Coyote. Fotografia: Tonino Delli Colli. Música: Vangelis. França/Inglaterra/EUA: Columbia Pictures Corporation/Burrill Productions/ Le Studio Canal+/Les Films Alain Sarde/R.P. Productions, 1992. 1 DVD (139min). Título original: Bitter moon.

PASOLINI, Pier Paolo. In: CARDOSO, Sergio. Os sentidos da paixão. São Paulo: Companhia das Letras, 1987.

\section{SOBRE OS AUTORES}

Bene Martins possui graduação em Pedagogia pela Universidade Federal do Pará (1987), mestrado em Letras: Lingüística e Teoria Literária pela Universidade Federal do Pará (1997) e doutorado em Letras pela Universidade Federal de Minas Gerais (2004). É professora adjunta da Escola de Teatro e Dança da Universidade Federal do Pará. Tem experiência na área de Letras e Artes, com ênfase em Letras, atuando principalmente nos seguintes temas: oralidade, memória, aspectos culturais da Amazônia, identidade, imaginário, alteridade e estereótipo, trocas interculturais, produção textual para cena, leituras dramatizadas, dramaturgia, avaliadora de peças/roteiros de minisséries televisivas. Professora do Programa de Pós-Graduação em Artes (PPGARTES) UFPA. Coordenadora do Projeto de Pesquisa: Memória da dramaturgia amazônida: construção do acervo dranatúrgico. Foi editora e revisora da Revista Ensaio GeralETDUFPA (2009-2014), é membro da Comissão Editorial da Revista Tucunduba-PROEX/UFPA e da Revista Ensaio Geral (ETDUFPA). Diretora Adjunta do Instituto de Ciências da Arte-ICAUFPA (dezembro/2010-dezembro/2014). Organizadora daobra completa: Peças Teatrais de Nazareno Tourinho, 2014; da coletânea Teatro do Pará, 2015, entre outros. Pósdoutora em Estudos de Teatro, com ênfase em Dramaturgia, na Universidade de Lisboa-PT, 2016. Estágio realizado com apoio CAPES. Coordenadora do Programa de Pós-Graduação em Artes (PPGARTES)-UFPA 
Marco Antonio Moreira tem Graduação em Administração pela Universidade Federal do Pará (1986), Pós-graduação em Marketing (1999) pela Fundação Getúlio Vargas/ldeal, Mestrado em Artes pela Universidade Federal do Pará (2015). Professor Substituto do curso de Cinema da UFPA (Universidade Federal do Pará)e professor (módulo I) do curso de pós-graduação de Produção Audiovisual na faculdade Estácio/ IESAM. Sou gestor da programação do Cinema Olympia (Belém-Pará), curador da Fundação Paraense de Rádio Difusão (FUNTELPA), membro da Academia Paraense de Ciências $(A P C)$, presidente da Associação dos Críticos de Cinema do Pará (ACCPA), apresentador / critico de cinema do Portal ORM (Organizações Rômulo Maiorana), crítico de cinema do Jornal \&quot; 0 Liberal\&quot; (Revista TROPPO), membro/ fundador da Associação Brasileira de Críticos de Cinema (ABRACCINE), consultor e assessor de Marketing da empresa Movie Cinemas Ltda., crítico de cinema e apresentador do programa de cinema ATUALIDADES CINEMATOGRÁFICAS na Rádio O Liberal AM, coordenador-geral do Centro de Estudos de Cinema(CEC) e professor de cursos de Cinema com atuação em várias instituições como UFPA, IESAM, CAIANA FILMES, SESC, EMATRA e CASA DAS ARTES. Tenho experiência nas áreas de Administração (com ênfase em Administração de Empresas) e Cinema (atuando principalmente nas atividades de instrução da cultura cinematográfica $e$ cineclubismo). 